\title{
Контроль распределения концентрации носителей заряда в гетероструктурах AlGaAs/GaAs
}

\author{
В.Е. Гончаров ${ }^{1,2)}$, А.В. Никонов ${ }^{1,3)}$ А.К. Ильясов ${ }^{1)}$ \\ ${ }^{1}$ АО «НПО «Орион», Москва, 111538, ул. Косинская, 9 \\ ${ }^{2}$ МИРЭА - Российский технологический университет, Москва, 119454, проспект Вернадского, 78 \\ ${ }^{3}$ МФТИ, Москва, 117303, ул. Керченская, д. 1А, корп. 1 \\ тел: +7 (499) 373-6011, эл. почта: vg10.orion@gmail.com
}

DOI 10.34077/RCSP2019-101

В технологии матричных фотоприемных устройств (МФПУ) для перспективных оптикоэлектронных систем инфракрасного диапазона спектра важным фактором является оптимизация фоточувствительного полупроводникового материала [1]. Фотоэлектрические характеристики, в частности, распределение концентрации носителей заряда по толщине эпитаксиальных структур, оказывают значительное влияние на качество фотоприемного устройства в целом, поэтому перед разработчиками остро стоит вопрос совершенствования комплекса методик контроля характеристик фоточувствительных материалов и гетероэпитаксиальных структур на их основе. В основе классических вольт-фарадных методов контроля фотоэлектрических характеристик многослойных структур для МФПУ II и III поколений лежит электронная теория приповерхностной области поверхностного заряда и дифференциальной емкости, но такие методы являются ограниченными по глубине профилирования концентрации носителей заряда [2-4]. Хорошей альтернативой традиционным методам является электрохимическое вольт-фарадное профилирование, позволяющее определять концентрацию носителей на глубине до десятков мкм [5].

При исследовании многослойных структур с различными уровнями легирования, в том числе квантоворазмерных, крайне важно знать, на какой глубине проводится профилирование при переходе от слоя к слою. Для анализа возможностей контроля концентрации по профилю отдельных эпитаксиальных слоев проведено исследование зависимости глубины области пространственного заряда от значений концентрации носителей в слое.

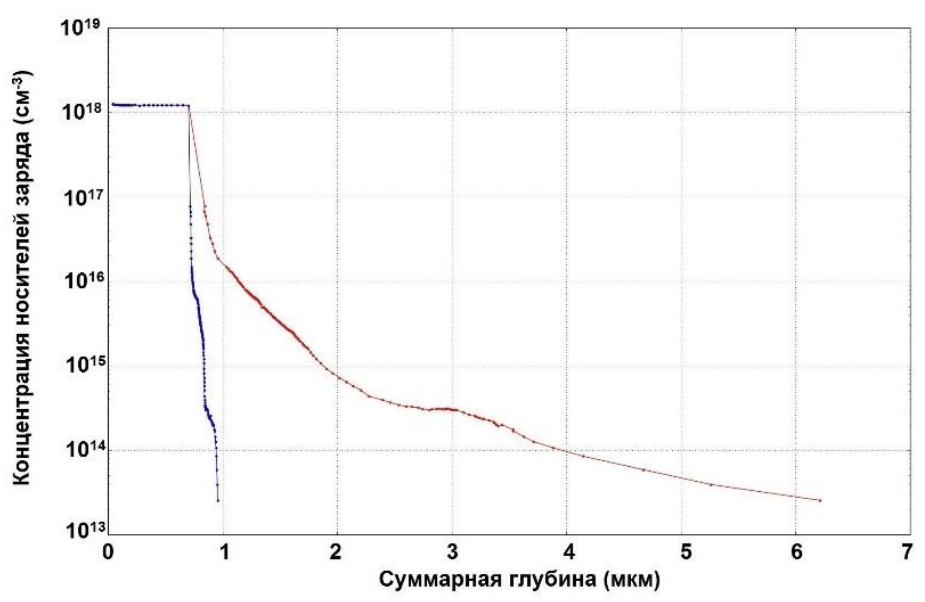

Проведены исследования распределения концентрации носителей заряда по профилю многослойных ГЭС соединений $\mathrm{A}^{\mathrm{III}} \mathrm{B}^{\mathrm{V}}$ на примере эпитаксиальных слоев GaAs и AlGaAs с различными значениями концентрации, выращенных на оптически прозрачных подложках $\mathrm{GaAs}<100>$.

Разработана расчетная аналитическая модель, позволяющая из измеренного ECVпрофиля установить значения толщины выращенных слоев и качество интерфейсов. Для выяснения возможностей контроля концентрации по профилю отдельных эпитаксиальных слоев проведено исследование зависимости глубины ОПЗ от значений концентрации носителей в слое. Данный метод является эффективным дополнением к существующим методикам входного и межоперационного контроля фоточувствительных материалов и структур.

\section{Лuтература}

[1] Дирочка А.И. и др. // Успехи прикладной физики. 2014. Т. 2. N 5. С. 509-519.

[2] Брунков П.Н. и др. // Физика и техника полупроводников. 2011. Т. 45. N 6. С. 829-835.

[3] Вакив Н.М. и др. // Технология и конструирование в электр. аппаратуре. 2005. N 3. C. 40-45.

[4] Груздов В.В. Контроль новых технологий в твердотельной СВЧ электронике / Груздов В.В.,

Колковский Ю.В., Концевой Ю.А. - Москва: Техносфера, 2016. - 327 с.

[5] Гончаров В.Е. и др. // Успехи прикладной физики. 2018. Т. 6. N 4. С. 290-296. 